\title{
ECONOMIC VOTING AND ELECTORAL BEHAVIOR: HOW DO INDIVIDUAL, LOCAL, AND NATIONAL FACTORS AFFECT THE PARTISAN CHOICE?
}

\author{
ANDREW LEIGH*
}

\begin{abstract}
What impact do income and other demographic factors have on a voter's partisan choice? Using post-election surveys of 14,000 voters in 10 Australian elections between 1966 and 2001, I explore the impact that individual, local, and national factors have on voters' decisions. In these 10 elections, the poor, foreign-born, younger voters, voters born since 1950 , men, and those who are unmarried are more likely to be left-wing. Over the past 35 years, the partisan gap between men and women has closed, but the partisan gap has widened on three dimensions: between young and old; between rich and poor; and between native-born and foreign-born. At a neighborhood level, I find that, controlling for a respondent's own characteristics, and instrumenting for neighborhood characteristics, voters who live in richer neighborhoods are more likely to be right-wing, while those in more ethnically diverse or unequal neighborhoods are more likely to be left-wing. Controlling for incumbency, macroeconomic factors do not seem to affect partisan preferences - Australian voters apparently regard both major parties as equally capable of governing in booms and busts.
\end{abstract}

IT IS something of a truism that, in a democracy, the partisan choice is the most important decision made by the citizenry. Economic growth, income distribution, social policies, and even the decision to go to war are often affected by whether one party or another is victorious. Yet for all this, there is surprisingly little attention paid by economists to understanding the differences between parties, and what makes voters choose one party over another.

One way of trying to understand what distinguishes political parties from one another is to compare outcomes under left-wing and right-wing governments (e.g. Alesina and Rosenthal, 1995; Alt and Lowry, 2000; Bartels, 2003; Leigh, 2005). Yet because elections are relatively rare events, one quickly runs out of degrees of freedom, particularly when controlling for

*I am grateful to Clive Bean, David Burchell, Sophie Holloway, and Ian McAllister for advice in navigating the various Australian election surveys, to Lisa Cameron and Mark Crosby for sharing their dataset on macroeconomic variables and vote share in Australian federal elections, and to Murray Goot, Bryan Palmer, Lindsay Tanner, an anonymous referee, and participants at the Australian Conference of Economists and the Australasian Political Science Association annual conference for valuable comments and suggestions on earlier drafts. All errors are mine.

Contact address: Andrew Leigh, Economics Program, Research School of Social Sciences, Australian National University ACT 0200, Australia. E-mail: andrew.leigh@anu.edu.au; web: www.andrewleigh.com 
other factors. An alternative way of understanding how left-wing and rightwing parties differ is to explore the revealed preferences of voters. If voters are quasi-rational, then systematic differences in partisan choice should reflect how parties' policies differentially affect groups within the society.

To explore this question further, I utilize data from Australia, a country which has the dual advantages of a stable bipartisan system and compulsory voting. In common with several developed nations, post-election surveys have been carried out in Australia for nearly four decades, making it possible to create a large repeated cross-sectional dataset - the first of its kind covering elections from 1966 to 2001. To presage my results, I find strong evidence that poorer voters, younger voters, those born since 1950, foreignborn Australians, and men are more likely to favor the left-wing Labor Party. Additionally, living in a poorer, more unequal, or more ethnically diverse neighborhood appears to make voters more likely to vote Labor. Lastly, using evidence from all Australian elections over the past century, I find no evidence of a systematic relationship between voters' ideological preferences and the state of the national economy.

The remainder of this paper is organized as follows. Section 1 sets out a model of voting behavior, and briefly reviews the relevant literature. Section 2 outlines the data. Section 3 explores individual-level evidence on voting patterns. Section 4 analyzes the effect of economic and ethnic differences at a neighborhood-level. Section 5 looks at national macroeconomic variables, and the final section concludes.

\section{A MODEL OF QUASI-RATIONAL PARTISAN VOTING}

Suppose that voter $i$ must choose whether or not to vote for a left-wing party, and that voting is compulsory, so that if she chooses not to vote for a left-wing party, she must vote for a right-wing party (I ignore the possibility that she might vote for a minor party or cast a spoiled ballot). ${ }^{1}$ The voter's decision will likely be determined by her expectation of how each party's policies will affect her. Since government policies affect groups, rather than individuals, we can characterize this effect as depending on particular groups to which the voter belongs $(X 1)$. Parties' policies may have a differing effect on people according to sex, age, year of birth, marital status, ethnic background, current income, or permanent income. These group-specific effects are not restricted to observable factors: policies may also have a differential impact upon unobservable groups $(X 2)$, such as the diligent and the lazy.

Further, the partisan choice may also be influenced by neighborhood effects (X3). For example, a voter dwelling in a neighborhood with few poor people may have less inclination to support anti-poverty policies than if the

\footnotetext{
${ }^{1}$ For simplicity, I maintain this coding throughout the paper. Thus, positive coefficients should always be interpreted as favoring the left-wing Labor Party, and negative coefficients as favoring the right-wing Coalition parties.
} 
same voter lived in a less affluent area. Neighborhoods may also affect voting patterns by influencing the way in which voters learn about parties' policies. Additionally, because voters choose where to live, group characteristics may be systematically related to neighborhood characteristics. I discuss below how to deal with this issue.

Voters may have some prior beliefs about which party is better able to manage the economy in a given situation $(X 4)$. For example, voters might prefer left-wing parties in a slump, since they are more generous with welfare payments, and believe that right-wing parties are better able to manage the economy in a boom, since they will keep inflation in check. Note that $X 4$ can include both the levels of macroeconomic variables, and their change over the course of the electoral cycle.

Lastly, voting preferences may be affected by what I will term "innate ideological attachment" (X5), unrelated to a voter's individual characteristics, locality, or the state of the national economy. Such ideological attachment may be a function of the group membership of the voter's parents (for example, a rich person's voting preferences may be affected by having grown up in a poor household), or to some factors about the voter's background that are not directly observable.

If we define $X 1$ as the observable groups to which an individual belongs, $X 2$ as unobservable group characteristics, $X 3$ as the characteristics of the individual's neighborhood, $X 4$ as national economic variables, and $X 5$ as the voter's innate ideological attachment, we can model the voting choice as:

$$
\operatorname{Pr}(\text { Vote for left-wing party })=f(X 1, X 2, X 3, X 4, X 5) .
$$

Although political scientists analyzing partisanship have often focused on party identification rather than on voting behavior, the above model nonetheless captures two important perspectives in the party identification literature. Those from the "Michigan School" tend to regard party identification as primarily a psychological attachment, heavily affected in childhood and largely immutable (Campbell et al., 1960, 1966). Revisionists, by contrast, believe that short-term influences such as party approval and candidate issue positions can have a strong effect on partisan identification and voting behavior (Franklin, 1984; Green and Palmquist, 1990). The "Michigan School" would see $X 5$ as the only important variable in the model, while revisionists would contend that $X 1, X 2, X 3$, and $X 4$ play a non-trivial role. ${ }^{2}$

\footnotetext{
${ }^{2}$ I am not aware of any studies which explicitly analyze these two perspectives through a rational voter framework, but it would seem that since parties sometimes change their policies, and voters sometimes experience unexpected changes in financial circumstances, the traditionalists' theory of party identification is more difficult to reconcile with a rational voter model than the revisionists' theory.
} 
Perhaps one surprising feature of the above model is that the incumbent party does not directly enter into the voter choice equation. ${ }^{3}$ During any election cycle, voters are assumed to update their beliefs about the impact that both parties' policies will have on their groups. For example, if the incumbent party pursues a set of anti-immigrant and anti-poor policies, then the voting behavior of a rich immigrant is indeterminate, and may depend on the political promises made by the opposition. However, it is still possible to derive the standard result from the macroeconomic voting literature from this model: if the economy performs badly over the election cycle, then (all else being equal) some voters who previously supported the incumbent will come to prefer the opposition party, and the incumbent will be more likely to be voted out of office. ${ }^{4}$

In the Australian context, most research on partisanship has been of two types. The first uses electorate-level evidence, exploring the extent to which a party's vote share in a given electorate is correlated with particular characteristics of that electorate (e.g., Jackman, 2003). While such evidence provides some overall sense of the underlying patterns, it suffers from a small sample size problem (there are only 150 federal electorates in Australia), and does not allow one to distinguish individual-level factors from neighborhood-level factors.

A second strand of the Australian literature has looked at the relationship between identities and voting behavior. Substantial literatures exist on the relationship between self-identified class and electoral behavior (McAllister, 1992; Goot, 1994; Charnock, 1997); post-materialist values and voting (Gow, 1990; Western and Tranter, 2001); as well as the relationship between attitudes to leadership and voting (Marks 1993). Yet because partisan identification and voting behavior are as much identities as class, post-materialist values, and attitudes towards political leaders, it is difficult to see how one might unpack the causal relationship. Just as class identification could affect party identification, so the reverse might be true. This is not true of the factors appearing in equation (1), which are either impossible to change (sex, age, ethnicity), or so fundamental that they are unlikely to be

\footnotetext{
${ }^{3}$ Some might go further yet, and argue that only incumbency, and not partisanship, should be included in the equation. Under the median voter theorem (Downs, 1957), politicians can be regarded as self-interested agents, interested not in ideology, but in the perquisites of office making the labels "A" and "B" just as informative as "left" and "right." Yet as Roemer (2001) points out, the median voter theorem quickly breaks down in the presence of multiple issues and uncertainty. As most close observers of politics will attest (and as the revealed preference results of this paper evidence), persistent ideological differences separate the major parties in most democratic nations.

${ }^{4}$ Note that if the effect depends on the individual's own finances (the "pocketbook effect"), it will affect $X 2$, while if it depends on macroeconomic conditions (the "sociotropic effect"), then it will affect $X 4$. For analyses comparing the salience of these two types of effects, see Lewis-Beck (1986) and Markus (1988).
} 
affected by a change in party identification (marital status, income, education, neighborhood). ${ }^{5}$ Moreover, the existing literature on voting patterns in Australia has focused on one or two post-election studies, while the present paper combines election studies over a 35 -year period, allowing analysis not only of the relationship between voting and demographics, but of how that relationship has changed over time.

\section{DATA}

To explore these questions further, I utilize data from various Australian election studies, conducted between 1966 and 2001. For the purposes of this study, some of the post-election surveys which were conducted cannot be used, since key questions were omitted from some of the surveys. The final sample covers 10 of the 16 elections to have been conducted in Australia over the past four decades: 1966, 1969, 1977, 1983, 1984, 1987, 1993, 1996, 1998, and 2001. Details of the surveys used appear in the Data Appendix. Table 1 presents summary statistics.

Since the start of the twentieth century, Australian politics has essentially been a two-party contest between the left-wing Labor Party and one or more conservative parties. ${ }^{6}$ From the 1940s, a conservative coalition has been maintained between the National Party (formerly known as the Country Party), and the Liberal Party. These two parties are typically referred to collectively as "the Coalition." I code respondents as 1 if they said that they voted for the Labor Party, and 0 if they voted for the Coalition. Respondents who said that they voted for any other party are coded as missing. Because the Australian electoral system allows for preferential voting, one would ideally like to take account of the second preferences of those who did not vote first for one of the major parties, but this question was unfortunately not asked in the earlier election surveys. According to Australian Electoral Commission statistics, over the 10 elections in my sample, 11.9 percent of the electorate did not cast a first preference vote for one of the major parties (the comparable figure for all elections between 1949 and 2001 is 9.5 percent).

How truthfully did respondents report how they voted? Table 2 shows the true vote shares reported by the Australian Electoral Commission and the breakdown of first preference votes reported in the surveys [columns (1)-(4)

\footnotetext{
${ }^{5}$ Could the causal arrow run from ideology to income? This would be possible, for example, if left-wing individuals were more likely to take on lower-paying public sector jobs. Unfortunately, we have little reliable evidence either on the public-private earnings gap in Australia, or on the propensity for more left-wing workers to choose public sector employment. However, the magnitude of this effect is limited by the fact that only 10 percent of Australian adults work in the public sector [Australian Bureau of Statistics, 2004, Wage and Salary Earners, Public Sector, Australia, Cat. No. 6248.0 (ABS, Canberra); and Australian Bureau of Statistics, 2004, Labour Force, Australia, Cat. No. 6202.0 (ABS, Canberra)].

${ }^{6}$ Though see also Mayer (1980, p.353), who argues that such a characterization is mere "chauvinism."
} 
Table 1 Summary Statistics

\begin{tabular}{lrrr}
\hline & Mean & Std. dev. & \multicolumn{1}{c}{$N$} \\
\hline Year of birth & $1,940.34$ & 19.10 & 13,957 \\
Age & 45.07 & 16.05 & 13,957 \\
Female & 0.49 & 0.50 & 13,957 \\
Married & 0.71 & 0.45 & 13,957 \\
Divorced & 0.06 & 0.24 & 13,957 \\
Family income (nominal A\$) & $23,810.10$ & $25,380.15$ & 13,957 \\
Years of education & 11.96 & 1.87 & 13,925 \\
Born overseas & 0.22 & 0.41 & 13,957 \\
Voted Labor (first preference) & 0.49 & 0.50 & 13,957 \\
Voted Labor (two-party preferred) & 0.46 & 0.50 & 5,103 \\
Labor in power when first voted & 0.33 & 0.47 & 13,957 \\
Election & $1,985.10$ & 11.59 & 13,957 \\
Mean income in neighborhood (in 1996) & $20,342.28$ & $4,020.17$ & 8,627 \\
Mean overseas-born in neighborhood (in 1996) & 0.22 & 0.12 & 8,627 \\
Gini in neighborhood (in 1996) & 0.44 & 0.02 & 8,627 \\
\hline
\end{tabular}

Table 2 Bias in Election Surveys

(1)

(2)

(3)

(4)

(5)

(6)

Survey after subsequent

Immediate survey election

Labor vote Labor Labor vote Over-reporting Labor vote Over-reporting

\begin{tabular}{lcccccc} 
Election & (actual) & won? & (survey) & of Labor vote & (survey) & of Labor vote \\
\hline 1966 & 0.445 & $\mathrm{~N}$ & 0.408 & -0.037 & 0.392 & -0.053 \\
1969 & 0.520 & $\mathrm{~N}$ & 0.499 & -0.021 & & \\
1975 & 0.446 & $\mathrm{~N}$ & & & 0.473 & 0.027 \\
1977 & 0.452 & $\mathrm{~N}$ & 0.478 & 0.026 & & \\
1980 & 0.493 & $\mathrm{~N}$ & & & 0.501 & 0.007 \\
1983 & 0.532 & $\mathrm{Y}$ & 0.572 & 0.041 & 0.603 & 0.071 \\
1984 & 0.514 & $\mathrm{Y}$ & 0.523 & 0.009 & 0.534 & 0.020 \\
1987 & 0.498 & $\mathrm{Y}$ & 0.529 & 0.030 & & \\
1990 & 0.476 & $\mathrm{Y}$ & & & 0.569 & 0.093 \\
1993 & 0.503 & $\mathrm{Y}$ & 0.507 & 0.003 & 0.512 & 0.009 \\
1996 & 0.451 & $\mathrm{~N}$ & 0.411 & -0.040 & 0.467 & 0.016 \\
1998 & 0.504 & $\mathrm{~N}$ & 0.485 & -0.019 & 0.477 & -0.027 \\
2001 & 0.468 & $\mathrm{~N}$ & 0.445 & -0.023 & & \\
Average & $\mathbf{0 . 4 8 4}$ & & $\mathbf{0 . 4 8 5}$ & $-\mathbf{0 . 0 0 1}$ & $\mathbf{0 . 5 1 3}$ & $\mathbf{0 . 0 2 6}$ \\
Average of & & & & $\mathbf{0 . 0 2 5}$ & & $\mathbf{0 . 0 3 6}$ \\
absolute values & & & & & & \\
\hline
\end{tabular}

Notes: In columns (5) and (6), the survey is the post-election survey for the following election. In effect, voters are asked to recall how they cast their ballot in a poll that occurred 2-4 years ago.

are relevant here, columns (5)-(6) will be discussed subsequently]. The mean absolute error is 2.5 percent, and in nine of the 10 elections, the results are biased in favor of the eventual election winner. We can also calculate the 
pro-winner bias, which is 1.9 percent. The pro-winner bias does not appear to be significantly stronger for either party. The pro-incumbent bias is just 0.4 percent. Overall, there is no evidence of a significant bias in favor of either party.

\section{INDIVIDUAL-LEVEL FACTORS}

To begin with, I explore the relationship between party preference and a basic set of demographic variables [the set of observable group characteristics described as $X 1$ in equation (1)]. This involves estimating the following regression.

$$
\operatorname{Pr}(\text { VoteLabor })_{i t}=\alpha+\beta Z_{i t}+\gamma_{t}+\varepsilon_{i t},
$$

where the dependent variable is a dummy that is 1 if the voter said that he or she had given their first preference vote to the Labor Party, and 0 if he or she had given their first preference vote to the Coalition (for simplicity, all outcomes in this paper will be denoted in the same fashion). $Z$ is a vector of voter-specific characteristics: sex, age, education, marital status, whether born overseas, education, and income. To take into account the fact that support for the two major parties varies from one election to the next, I also include an election-specific fixed effect, $\gamma$ (this term absorbs any retrospective voting effects). To estimate this regression, I use a probit model, though results are not substantially different if a logit model is used instead.

The first column of Table 3 shows the results of this specification. Being female, older, richer, better educated, married, or born in Australia predicts that individuals will be more likely to vote for the Coalition, and less likely to vote Labor. ${ }^{7}$ Columns (2) and (3) then re-run the specification for the first and last elections in the sample, to see how these coefficients have changed. Some clear changes are observable over this time period. Older Australians were more likely to vote for the Coalition in 2001 than they were in 1966. Income polarization can also be observed, with poorer voters becoming more likely to vote Labor, and richer voters becoming more likely to vote for the Coalition. In addition, the gender gap (controlling for other factors such as education and family income) appears to have disappeared in 2001.

To ensure that the differences between the coefficients in 1966 and 2001 represent a long-run trend, column (4) uses all 10 election surveys, and interacts a linear time trend with each of the demographic variables.

$$
\operatorname{Pr}(\text { VoteLabor })_{i t}=\alpha+\beta_{1} Z_{i t}+\beta_{2} Z_{i t} T_{t}+\gamma_{t}+\varepsilon_{i t} .
$$

For simplicity, the primary coefficients on the demographic variables $\left(\beta_{1}\right)$ are not shown in Table 3, and the coefficients on the time trends $\left(\beta_{2}\right)$ are normalized so that a one-unit change represents the total change over the

\footnotetext{
${ }^{7}$ Of course, it might be the case that the age effect is really a cohort effect. I explore this issue in more detail in section 3.4 .
} 
Table 3 How Do Individual Demographics Affect Voting?

(Dependent variable: 1 if voted Labor, 0 if voted Coalition)

\begin{tabular}{|c|c|c|c|c|}
\hline & $\begin{array}{l}(1) \\
\text { All }\end{array}$ & $\begin{array}{c}(2) \\
1966\end{array}$ & $\begin{array}{c}(3) \\
2001\end{array}$ & $\begin{array}{c}\text { (4) } \\
\text { Trend coef. }\end{array}$ \\
\hline Trend & & & & $\begin{array}{c}0.063 \\
{[0.056]}\end{array}$ \\
\hline Aged 30-39 & $\begin{array}{c}0.006 \\
{[0.015]}\end{array}$ & $\begin{array}{c}0.003 \\
{[0.045]}\end{array}$ & $\begin{array}{c}-0.019 \\
{[0.053]}\end{array}$ & $\begin{array}{c}0.053 \\
{[0.046]}\end{array}$ \\
\hline Aged $40-49$ & $\begin{array}{r}-0.029^{*} \\
{[0.015]}\end{array}$ & $\begin{array}{c}0.112^{* *} \\
{[0.045]}\end{array}$ & $\begin{array}{c}-0.041 \\
{[0.053]}\end{array}$ & $\begin{array}{c}-0.105^{* *} \\
{[0.046]}\end{array}$ \\
\hline Aged $50-59$ & $\begin{array}{c}-0.099^{* * *} \\
{[0.016]}\end{array}$ & $\begin{array}{c}0.053 \\
{[0.047]}\end{array}$ & $\begin{array}{c}-0.131^{* *} \\
{[0.052]}\end{array}$ & $\begin{array}{l}-0.125^{* * *} \\
{[0.048]}\end{array}$ \\
\hline Aged 60 or over & $\begin{array}{c}-0.166^{* * *} \\
{[0.014]}\end{array}$ & $\begin{array}{r}-0.083^{*} \\
{[0.046]}\end{array}$ & $\begin{array}{c}-0.251^{* * *} \\
{[0.048]}\end{array}$ & $\begin{array}{l}-0.134^{* * *} \\
{[0.048]}\end{array}$ \\
\hline Income quintile 2 & $\begin{array}{c}-0.042^{* * *} \\
{[0.014]}\end{array}$ & $\begin{array}{c}-0.075^{* *} \\
{[0.037]}\end{array}$ & $\begin{array}{c}-0.134^{* * *} \\
{[0.044]}\end{array}$ & $\begin{array}{c}-0.075^{*} \\
{[0.041]}\end{array}$ \\
\hline Income quintile 3 & $\begin{array}{c}-0.082^{* * *} \\
{[0.015]}\end{array}$ & & $\begin{array}{c}-0.193^{* * *} \\
{[0.044]}\end{array}$ & $\begin{array}{c}0.046 \\
{[0.051]}\end{array}$ \\
\hline Income quintile 4 & $\begin{array}{c}-0.119^{* * * *} \\
{[0.015]}\end{array}$ & $\begin{array}{c}-0.236^{* * *} \\
{[0.035]}\end{array}$ & $\begin{array}{c}-0.212^{* * *} \\
{[0.044]}\end{array}$ & $\begin{array}{c}0.085^{*} \\
{[0.045]}\end{array}$ \\
\hline Income quintile 5 & $\begin{array}{c}-0.197^{* * *} \\
{[0.015]}\end{array}$ & $\begin{array}{c}-0.377^{* * *} \\
{[0.028]}\end{array}$ & $\begin{array}{c}-0.281^{* * *} \\
{[0.042]}\end{array}$ & $\begin{array}{l}0.140^{* * *} \\
{[0.048]}\end{array}$ \\
\hline High school only & $\begin{array}{c}-0.102^{* * *} \\
{[0.014]}\end{array}$ & $\begin{array}{c}-0.059 \\
{[0.037]}\end{array}$ & $\begin{array}{c}-0.052 \\
{[0.051]}\end{array}$ & $\begin{array}{c}0.046 \\
{[0.043]}\end{array}$ \\
\hline Diploma/trade & $\begin{array}{c}-0.061^{* * *} \\
{[0.011]}\end{array}$ & $\begin{array}{c}-0.082^{* *} \\
{[0.037]}\end{array}$ & $\begin{array}{c}-0.047 \\
{[0.038]}\end{array}$ & $\begin{array}{c}0.045 \\
{[0.036]}\end{array}$ \\
\hline University degree & $\begin{array}{c}-0.025 \\
{[0.016]}\end{array}$ & $\begin{array}{c}-0.084 \\
{[0.082]}\end{array}$ & $\begin{array}{c}0.065 \\
{[0.048]}\end{array}$ & $\begin{array}{c}0.031 \\
{[0.058]}\end{array}$ \\
\hline Born overseas & $\begin{array}{l}0.057^{* * *} \\
{[0.011]}\end{array}$ & $\begin{array}{c}-0.034 \\
{[0.034]}\end{array}$ & $\begin{array}{l}0.153^{* * *} \\
{[0.034]}\end{array}$ & $\begin{array}{l}0.129^{* * *} \\
{[0.033]}\end{array}$ \\
\hline Female & $\begin{array}{c}-0.076^{* * *} \\
{[0.009]}\end{array}$ & $\begin{array}{c}-0.135^{* * *} \\
{[0.027]}\end{array}$ & $\begin{array}{c}-0.009 \\
{[0.029]}\end{array}$ & $\begin{array}{l}0.098^{* * *} \\
{[0.028]}\end{array}$ \\
\hline Married & $\begin{array}{c}-0.037^{* * *} \\
{[0.012]}\end{array}$ & $\begin{array}{c}0.027 \\
{[0.037]}\end{array}$ & $\begin{array}{c}-0.034 \\
{[0.042]}\end{array}$ & $\begin{array}{c}-0.069^{*} \\
{[0.038]}\end{array}$ \\
\hline Divorced & $\begin{array}{c}0.006 \\
{[0.021]}\end{array}$ & & $\begin{array}{c}-0.024 \\
{[0.062]}\end{array}$ & $\begin{array}{l}-0.057 \\
{[0.075]}\end{array}$ \\
\hline Election FE? & Yes & No & No & Yes \\
\hline Observations & 13,957 & 1,448 & 1,259 & 13,957 \\
\hline Pseudo- $R^{2}$ & 0.03 & 0.08 & 0.05 & 0.04 \\
\hline Observed probability & 0.49 & 0.42 & 0.45 & 0.49 \\
\hline
\end{tabular}

Notes: Coefficients are marginal effects from a probit model. ${ }^{*},{ }^{* *}$, and ${ }^{* * *}$ denote statistical significance at the $10 \%, 5 \%$, and $1 \%$ level, respectively. Robust standard errors in square brackets. Excluded categories are as follows: age - those aged 18-29; income - first quintile; education - high school dropouts. Column (4) shows the coefficients on a time trend interacted with the demographic variable, where the time trend is normalized such that a one-unit increase denotes the average change from 1966 to 2001. In this model, the demographics are also included as main effects, but their coefficients are not shown. 


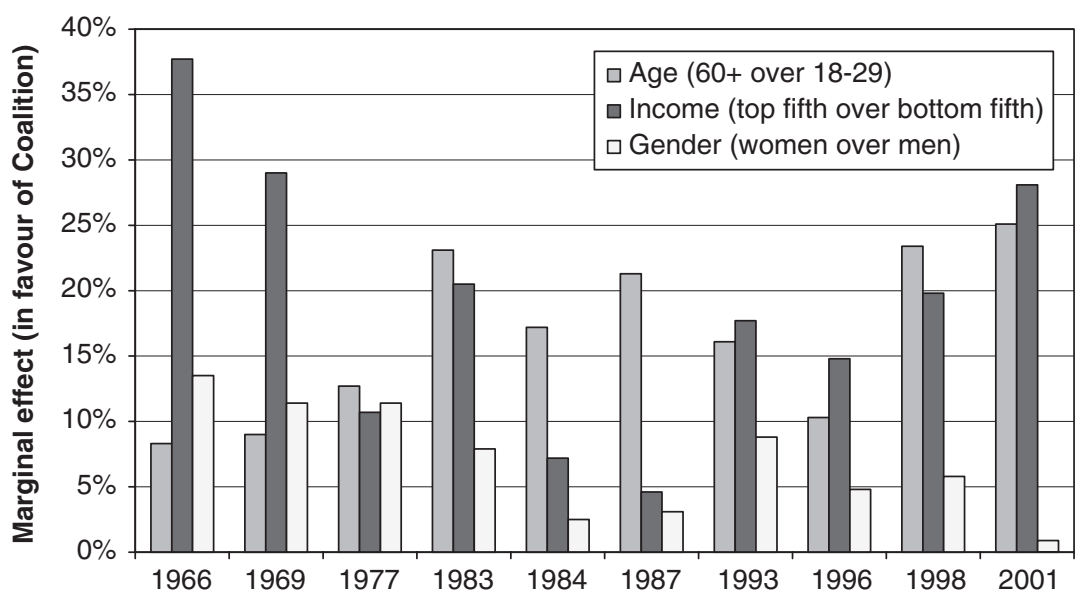

Figure 1. How have age, income, and gender gaps changed over time?

Note: This figure repeats the exercise presented in columns (2) and (3) of Table 3 for every election in the sample. In each case, it depicts three coefficients: age $60+$, income quintile 5 , and female.

35-year period 1966 to 2001. In general, the trend coefficients support the patterns observed from simply comparing the 1966 and 2001 election surveys. Figure 1 presents selected coefficients in a graphical form - showing the marginal effect of age, income, and gender on voting patterns in each election.

I now turn to exploring the demographic factors in more detail.

\subsection{A Disappearing Gender Gap?}

Edlund and Pande (2001) have shown that, since the early 1970s, US women have favored the Democrats over the Republicans. Conversely, in most European countries, men were more left-wing than women from the 1970s until the mid-1990s. However, Edlund and Pande identify a common trend on both sides of the Atlantic: since the 1970s, US and European women have steadily become more left-wing.

What about Australia? The tendency of women to favor the Coalition has been noted by several researchers (see Aitkin, 1982; Renfrow, 1994). In an innovative analysis, Leithner (1997) uses variation in gender composition across electorates to show that over the 1910-1966 period, women were about 4 percentage points more likely to vote for the Coalition. ${ }^{8}$ The Australian gender voting gap persisted through the 1980s and 1990s; had only women voted, Labor Prime Minister Paul Keating would have lost the 1993 election.

\footnotetext{
${ }^{8}$ This 4 percent figure excludes the 1917 election, in which conscription was a major issue, and excludes those who voted for minor parties.
} 
But as in the US and Europe, Australian women have steadily become more left-wing. By 2001, the Australian gender voting gap had entirely disappeared, regardless of whether or not one controls for other demographic variables. Looking first at the raw gender gap (without controlling for other factors) the difference between the sexes used to be substantial. In the 1960s, women were much more likely than men to vote for the Coalition, by a margin of 8 percent in 1966 and 9 percent in 1969. But the raw gap was down to 4 percent in 1996, and 3 percent in 1998. In 2001 the pattern had reversed, with women 2 percent less likely to vote for the Coalition than men.

The same story emerges when analyzing the controlled gender gap. As Figure 1 shows, the gender gap in Australia, controlling for other factors, was 14 and 11 percent in the 1966 and 1969 elections, but just 5 and 6 percent in the 1996 and 1998 elections, respectively. In 2001, the controlled gender gap was 1 percent, indistinguishable from zero at conventional levels of significance.

What might explain this change? In the US context, Edlund and Pande (2001) find that lower marriage rates and higher divorce rates account for much of the change. In terms of size-equivalized family income, divorce tends to make women poorer and men richer (the same is true in Australia: Weston and Smyth, 2000). Hence, more divorce should result in women being more likely to support the Democratic Party. This should hold even after controlling for income, since divorce will reduce permanent income as well as current income. Edlund and Pande find a strong relationship across US states between divorce rates and the political gender gap, and observe that after divorce, women are more likely to support the Democrats, and men are more likely to support the Republicans. Edlund et al. (2005) also find support for this theory across nine Western European countries.

An alternative theory might be derived from Leithner (1997), who finds a partisan gap between male and female trade union members, but no gender gap between those who are not members of a trade union. Leithner does not explore the dynamics of this in detail, but if one were to take union membership as exogenous, it could be posited that the decline in union membership since the 1960s was responsible for the closing of the gender gap. As union membership goes to zero, its differential impact on the gender gap could be expected to fall to zero. And indeed, union membership in Australia has declined sharply in recent years. Union membership in Australia was around 45 percent of the workforce from the 1960s until the mid-1980s, fell to 40 percent in the early 1990 s, and had dropped to 25 percent in $2001 .^{9}$

\footnotetext{
${ }^{9}$ Union membership data prior to 1988 is based on figures reported by unions. Trade union membership was published by the Australian Bureau of Statistics in its annual Labour Reports publications, and then in Trade Union Statistics (ABS Cat. No. 6323.0). From 1988 onwards, unionization rates are available on a survey basis [Australian Bureau of Statistics, 2002, Employee Earnings, Benefits and Trade Union Membership, Cat. No. 6310.0 (ABS, Canberra) and its predecessor publications, beginning as Cat. No. 6325.0].
} 
Table 4 provides further evidence on these two hypotheses. Columns (1) and (2) re-analyze the sample, restricting the dataset to women and men only. A number of differences are immediately apparent. Age appears to have a stronger effect on the voting patterns of women, while income seems to have a stronger effect on the voting patterns of men. Being born overseas has a stronger impact on the propensity of women to vote Labor than men. Being married makes both men and women more likely to vote for the Coalition, but has a larger impact on men than women. Neither of the coefficients on divorce is statistically significant, though the signs are consistent with Edlund and Pande's findings for the US (pro-Labor for women, pro-Coalition for men).

Column (3) adds three new coefficients - union member, female $*$ union member, and female $*$ non-union member. The results support Leithner's trade union hypothesis (which were based only on data from 1993), across the pooled 1966-2001 sample. The coefficient on female $*$ union member is -0.14 , which is significant at the 1 percent level, while the coefficient on female $*$ non-union member is small and insignificant.

Yet care should be taken in interpreting these results. While Leithner appears to treat union membership as exogenous to party preference, it is difficult to see how this can be entirely true. Even if union membership is compulsory in certain workplaces, employees can still decide whether to join a union: by choosing between unionized and non-unionized occupations. The foregoing results provide some suggestive evidence that the decline of unionization is responsible for the narrowing of the political gender gap, but without a credible source of exogenous variation in union membership, it is difficult to be sure of this.

\subsection{Education}

As Table 3 shows, completing high school and having a trade qualification are both negatively correlated with voting Labor. Controlling for other demographics (including current income), high school graduates are 10 percent more likely than high school dropouts to vote for the Coalition, while those with a trade qualification are 6 percent more likely than high school dropouts to support the Coalition. However, the relationship between education and voting is not monotonic. Those with a university degree are 3 percent more likely to vote Labor, but this marginal effect is indistinguishable from zero at conventional levels of significance $(p=0.12)$. Further tests also reveal that the high school graduate coefficient, the trade qualification coefficient, and the university coefficient are all distinguishable from one another at the 5 percent level or better.

What explains these patterns? First, it might be the case that what really matters is permanent income, not education, and education might merely be a strong proxy for what a person can expect to earn over his or her lifetime. 
Table 4 What Explains the Gender Gap? (Dependent variable: 1 if voted Labor, 0 if voted Coalition)

\begin{tabular}{|c|c|c|c|}
\hline & $\begin{array}{c}(1) \\
\text { Women }\end{array}$ & $\begin{array}{l}(2) \\
\text { Men }\end{array}$ & $\begin{array}{l}\text { (3) } \\
\text { Both }\end{array}$ \\
\hline Aged 30-39 & $\begin{array}{c}-0.020 \\
{[0.021]}\end{array}$ & $\begin{array}{c}0.040^{*} \\
{[0.021]}\end{array}$ & $\begin{array}{l}0 \\
{[0.016]}\end{array}$ \\
\hline Aged 40-49 & $\begin{array}{c}-0.051^{* *} \\
{[0.021]}\end{array}$ & $\begin{array}{c}0.002 \\
{[0.022]}\end{array}$ & $\begin{array}{c}-0.037^{* *} \\
{[0.016]}\end{array}$ \\
\hline Aged $50-59$ & $\begin{array}{c}-0.129^{* * *} \\
{[0.021]}\end{array}$ & $\begin{array}{c}-0.058^{* *} \\
{[0.023]}\end{array}$ & $\begin{array}{c}-0.097^{* * *} \\
{[0.016]}\end{array}$ \\
\hline Aged 60 or over & $\begin{array}{c}-0.193^{* * *} \\
{[0.020]}\end{array}$ & $\begin{array}{c}-0.129^{* * *} \\
{[0.022]}\end{array}$ & $\begin{array}{c}-0.139^{* * *} \\
{[0.016]}\end{array}$ \\
\hline Income quintile 2 & $\begin{array}{c}-0.031^{*} \\
{[0.018]}\end{array}$ & $\begin{array}{c}-0.058^{* * *} \\
{[0.021]}\end{array}$ & $\begin{array}{c}-0.062^{* * *} \\
{[0.014]}\end{array}$ \\
\hline Income quintile 3 & $\begin{array}{c}-0.095^{* * *} \\
{[0.020]}\end{array}$ & $\begin{array}{c}-0.081^{* * *} \\
{[0.023]}\end{array}$ & $\begin{array}{c}-0.099^{* * *} \\
{[0.016]}\end{array}$ \\
\hline Income quintile 4 & $\begin{array}{c}-0.118^{* * *} \\
{[0.020]}\end{array}$ & $\begin{array}{c}-0.131^{* * *} \\
{[0.022]}\end{array}$ & $\begin{array}{c}-0.139^{* * *} \\
{[0.015]}\end{array}$ \\
\hline Income quintile 5 & $\begin{array}{c}-0.175^{* * *} \\
{[0.021]}\end{array}$ & $\begin{array}{c}-0.221^{* * *} \\
{[0.022]}\end{array}$ & $\begin{array}{c}-0.212^{* * *} \\
{[0.015]}\end{array}$ \\
\hline High school only & $\begin{array}{c}-0.099^{* * *} \\
{[0.019]}\end{array}$ & $\begin{array}{c}-0.100^{* * * *} \\
{[0.020]}\end{array}$ & $\begin{array}{c}-0.086^{* * *} \\
{[0.015]}\end{array}$ \\
\hline Diploma/trade & $\begin{array}{c}-0.101^{* * *} \\
{[0.016]}\end{array}$ & $\begin{array}{r}-0.031^{*} \\
{[0.016]}\end{array}$ & $\begin{array}{c}-0.064^{* * *} \\
{[0.012]}\end{array}$ \\
\hline University degree & $\begin{array}{c}-0.011 \\
{[0.023]}\end{array}$ & $\begin{array}{c}-0.036 \\
{[0.023]}\end{array}$ & $\begin{array}{c}-0.023 \\
{[0.017]}\end{array}$ \\
\hline Born overseas & $\begin{array}{l}0.075^{* * *} \\
{[0.016]}\end{array}$ & $\begin{array}{l}0.040^{* * *} \\
{[0.015]}\end{array}$ & $\begin{array}{c}0.054^{* * *} \\
{[0.012]}\end{array}$ \\
\hline Married & $\begin{array}{c}-0.034^{* *} \\
{[0.017]}\end{array}$ & $\begin{array}{c}-0.054^{* * *} \\
{[0.018]}\end{array}$ & $\begin{array}{c}-0.026^{* *} \\
{[0.013]}\end{array}$ \\
\hline Divorced & $\begin{array}{c}0.007 \\
{[0.027]}\end{array}$ & $\begin{array}{c}-0.009 \\
{[0.033]}\end{array}$ & $\begin{array}{c}0.004 \\
{[0.022]}\end{array}$ \\
\hline Union member & & & $\begin{array}{l}0.277^{* * *} \\
{[0.013]}\end{array}$ \\
\hline Female $*$ Union & & & $\begin{array}{c}-0.142^{* * *} \\
{[0.018]}\end{array}$ \\
\hline Female $*$ Non-Union & & & $\begin{array}{c}-0.005 \\
{[0.011]}\end{array}$ \\
\hline Election FE? & Yes & Yes & Yes \\
\hline Observations & 6,828 & 7,129 & 12,718 \\
\hline Pseudo- $R^{2}$ & 0.03 & 0.03 & 0.06 \\
\hline Observed probability & 0.47 & 0.51 & 0.48 \\
\hline
\end{tabular}

Notes: Coefficients are marginal effects from a probit model. ${ }^{*},{ }^{* *}$, and ${ }^{* * *}$ denote statistical significance at the $10 \%, 5 \%$, and $1 \%$ level, respectively. Robust standard errors in square brackets. Excluded categories are as follows: age - those aged 18-29; income - first quintile; education - high school dropouts. Column (3) excludes the 1983 election survey, which did not ask about union membership. 
Second, parties' policies on higher education might have a differential impact on voting patterns by those with varying qualifications (it seems unlikely that this would be a major factor, since in practice education reforms typically only affect the small fraction of voters who are at university, not those who have already graduated with a given qualification). Third, those who do not pursue formal education could experience a different form of socialization from those who do complete formal education, and could adopt differing sets of partisan preferences as a result.

A way of separating the first factor from the other two is to restrict the sample to those whose current income is most likely to be equal to their permanent income. ${ }^{10}$ An obvious group is males aged 35-55, a group who have relatively high labor force participation rates. Table 5 shows the results of this regression. Here, the only education variable which remains statistically significant is finishing high school, suggesting that there may be some difference in political socialization between those who drop out of high school and the rest of the population. However, beyond high school, education appears to only impact on voting patterns through the permanent income effect.

\subsection{Income}

The positive relationship between income and support for a right-wing party is perhaps the least surprising result in this paper. Yet it is worth exploring whether non-linearities exist. In a univariate analysis, conducted at the electorate level, Jackman (2003) finds a non-linear relationship between electorate median income and Labor support across all seats, but a linear relationship when the analysis is confined to urban seats only.

In the foregoing analysis, income has been presented in quintiles, but to explore the issue of non-linearities further, the focus is narrowed to income deciles. To see this graphically, I estimate equation (2), excluding income. Figure 2 then charts the residuals from this regression against income deciles. In general, the relationship is monotonic - at any point, more income makes voters more likely to support the Coalition. But it also appears that the effect is strongest for the top and bottom deciles. Controlling for other factors, those in the bottom decile are 7 percent more likely to vote Labor, while those in the top decile are 15 percent less likely to vote Labor.

As Figure 1 shows, the partisan gap between rich and poor voters fell during the 1960s, and rose again during the 1990s (a similar rise can also be seen in the US: Stonecash and Mariani, 2000). Adopting the revealed preference approach, this suggests that the Labor Party of today is more propoor than the Labor Party of the 1970s and 1980s; that the Coalition of

\footnotetext{
${ }^{10}$ For an excellent discussion of transitory and permanent income, see Haider and Solon (2004).
} 
Table 5 Education or Permanent Income?

(Dependent variable: 1 if voted Labor, 0 if voted Coalition)

\begin{tabular}{|c|c|}
\hline & Men aged $35-55$ only \\
\hline Aged $40-49$ & $\begin{array}{c}-0.023 \\
{[0.023]}\end{array}$ \\
\hline Aged $50-59$ & $\begin{array}{c}-0.063^{* *} \\
{[0.027]}\end{array}$ \\
\hline Income quintile 2 & $\begin{array}{c}0.032 \\
{[0.042]}\end{array}$ \\
\hline Income quintile 3 & $\begin{array}{c}-0.003 \\
{[0.042]}\end{array}$ \\
\hline Income quintile 4 & $\begin{array}{c}-0.092^{* *} \\
{[0.040]}\end{array}$ \\
\hline Income quintile 5 & $\begin{array}{c}-0.194^{* * *} \\
{[0.040]}\end{array}$ \\
\hline High school graduation only & $\begin{array}{c}-0.081^{* *} \\
{[0.032]}\end{array}$ \\
\hline Diploma/trade qualification & $\begin{array}{c}0.001 \\
{[0.025]}\end{array}$ \\
\hline University degree & $\begin{array}{c}0.043 \\
{[0.034]}\end{array}$ \\
\hline Born overseas & $\begin{array}{l}0.077^{* * *} \\
{[0.022]}\end{array}$ \\
\hline Married & $\begin{array}{c}-0.026 \\
{[0.035]}\end{array}$ \\
\hline Divorced & $\begin{array}{c}-0.024 \\
{[0.050]}\end{array}$ \\
\hline Election FE? & Yes \\
\hline Observations & 3,003 \\
\hline Pseudo- $R^{2}$ & 0.03 \\
\hline Observed probability & 0.51 \\
\hline
\end{tabular}

Notes: Coefficients are marginal effects from a probit model. ${ }^{*},{ }^{* *}$, and ${ }^{* * *}$ denote statistical significance at the $10 \%, 5 \%$, and $1 \%$ level, respectively. Robust standard errors in square brackets. Excluded categories are as follows: age - those aged 35-39; income - first quintile; education - high school dropouts.

today is more pro-rich; or perhaps some combination of the two. ${ }^{11}$ The revealed preference approach also suggests from Figure 2 that the policy difference between the two parties is greatest in their treatment of the very

\footnotetext{
${ }^{11}$ One reader of an earlier draft of this paper suggested that diverging voting patterns among rich and poor might be due to the fact that inequality has risen in Australia since the 1960s (for evidence on long-run trends in Australian inequality, see Leigh, 2004). However, as will be shown in Table 10, the cross-sectional effect of inequality during the 1990s was to make voters more likely to support the Labor Party, with the impact being strongest on the rich. Though it is plausible that the effect of inequality on the income-voting relationship over time operates in the reverse direction to the effect of inequality in the cross-section, the results in Table 10 provide some evidence to suggest that higher inequality does not explain the growing income voting gap.
} 


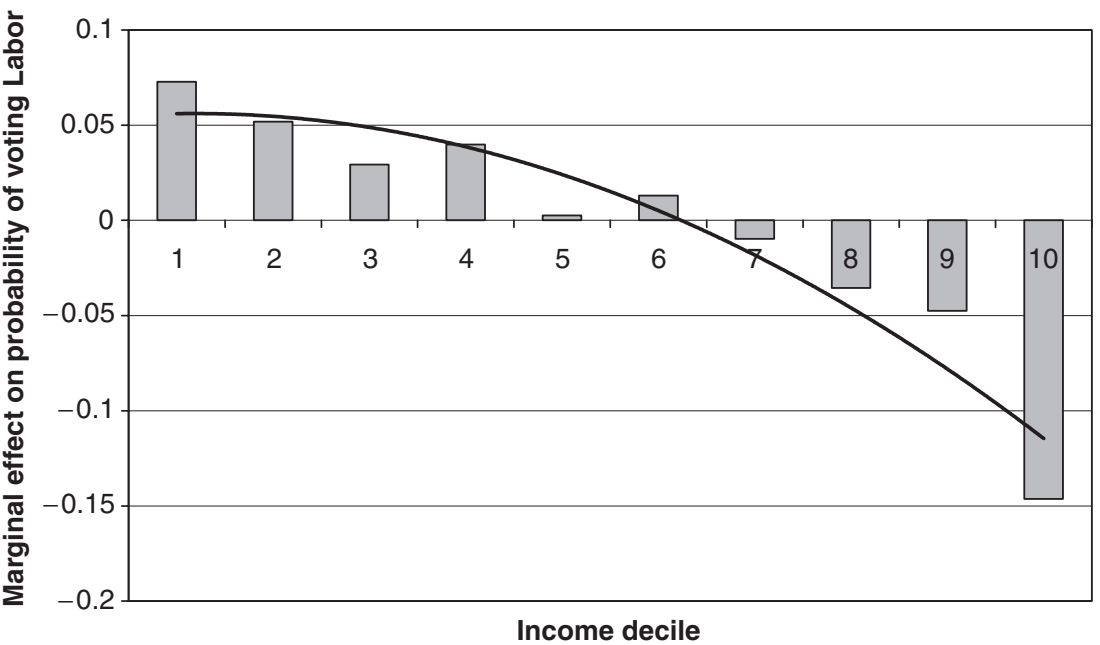

Figure 2. Is the relationship between voting and income non-linear?

Note: This figure runs the regression in column (1) of Table 3, excluding income, and plots the residuals against income deciles. The trend line is a quadratic.

poor and the very rich - a factor which appears to shed new light on the debate over party convergence (for a summary, see Goot, 2004).

\subsection{Age and Cohort Effects}

Until this point, I have included only age in the model, and characterized the results as showing that older voters are more likely to support the Coalition. Yet this is something of an over-simplification. While it could perhaps be the case that individuals are more likely to support the Coalition as they age, it might instead be the case that those born earlier in the century were more conservative than their children. (Of course, for this to be true, some other offsetting demographic shift would have to be present, given that Labor won two elections in the 1970s.)

However, if one includes age and birth year in the model, then it is necessary to omit election fixed effects. Assuming that there is some fluctuation across elections that cannot be explained by age and cohort effects, such an approach is likely to be problematic.

To solve this problem, I divide the sample into four cohorts: those born before 1930, between 1930 and 1944, between 1945 and 1960, and after 1960 (the sample is too small to further break down the youngest cohort). In place of election fixed effects, I calculate for each cohort the fraction of voters in other cohorts who supported the ALP at that election. This "average ALP vote" variable captures factors that have nothing to do with age or cohort effects, such as the popularity of the party leaders at a given election. It is 
Table 6 Separating Age and Cohort Effects

(Dependent variable: 1 if voted Labor, 0 if voted Coalition)

\begin{tabular}{lcccc}
\hline & $(1)$ & $(2)$ & $(3)$ & $(4)$ \\
Cohort born: & Pre-1930 & $1930-1944$ & $1945-1960$ & Post-1960 \\
\hline Aged 30-39 & & -0.008 & -0.004 & $0.056^{* *}$ \\
& & {$[0.034]$} & {$[0.023]$} & {$[0.028]$} \\
Aged 40-49 & 0.076 & $-0.077^{* *}$ & $-0.060^{* *}$ & 0.014 \\
& {$[0.061]$} & {$[0.038]$} & {$[0.025]$} & {$[0.095]$} \\
Aged 50-59 & -0.010 & $-0.117^{* * *}$ & $-0.136^{* * *}$ & \\
& {$[0.060]$} & {$[0.034]$} & {$[0.034]$} & \\
Aged 60 or over & $-0.104^{*}$ & $-0.161^{* * *}$ & & \\
& {$[0.060]$} & {$[0.033]$} & & \\
Average ALP vote in that & $0.461^{* * *}$ & $1.808^{* * *}$ & $0.744^{* * *}$ & $0.898^{* * *}$ \\
election by other birth cohorts & {$[0.128]$} & {$[0.263]$} & {$[0.212]$} & {$[0.236]$} \\
Controls for income, education, & Yes & Yes & Yes & Yes \\
$\quad$ sex, born OS, marital status? & & & & \\
Observations & 4,188 & 3,448 & 4,250 & 2,071 \\
Pseudo- $R^{2}$ & 0.04 & 0.05 & 0.03 & 0.02 \\
Observed probability & 0.46 & 0.45 & 0.52 & 0.55 \\
\hline
\end{tabular}

Notes: Coefficients are marginal effects from a probit model. ${ }^{*},{ }^{* *}$, and ${ }^{* * *}$ denote statistical significance at the $10 \%, 5 \%$, and $1 \%$ level, respectively. Robust standard errors in square brackets. Excluded age category is those aged 30-39 in column 1, and 18-29 in columns 3-4.

now possible to see whether there are still within-cohort age effects, and how these age coefficients compare across cohorts. For simplicity, Table 6 shows only the age coefficients, though the model also includes controls for income, education, sex, born overseas, and marital status.

The results from Table 6 suggest that most of the effect is due to age patterns, rather than cohort effects, with the age coefficients for the first three cohorts appearing to be quite similar. The largest age coefficients are for those aged 50-59, and those aged 60 and over. Using the revealed preference approach, this suggests that the Coalition's policies are significantly more generous towards retirees than Labor's.

The only group for which cohort effects may matter is those born after 1960, a group that does not exhibit the same lifecycle pattern as earlier cohorts. This could be due to one of two factors. One possible explanation is that a cohort effect is at work - since the results in Table 6 are consistent with the baby boomers being more left-wing than their parents (and differing little in ideological terms from Generations X and Y). Alternatively, it might be that the partisan age gap has widened over recent decades. As Figure 1 indicates, the partisan gap between voters 18-29, and voters aged 60 and over, favored the Coalition by 8 and 9 percent respectively in the 1966 and 1969 elections, but by 23 and 25 percent respectively in the 1998 and 2001 elections. While it is not possible to distinguish between a cohort effect and a 
changing age effect, it is notable that both theories have received anecdotal support, with some arguing that the socializing experience of growing up in the 1960s and 1970s led that cohort to be more progressive than their forebears, and others contending that the Coalition government's policies since 1996 have been particularly successful in winning the support of older voters (e.g., Grattan, 2004).

\subsection{Overseas-Born Voters}

Throughout the sample period, foreign-born workers were more likely to support Labor than the native-born. Moreover, the tendency of foreignborn voters to support Labor increased from 1966 to 2001. As column (4) of Table 3 shows, Labor's advantage among those born outside Australia rose by 13 percent over this period. Although most developed countries have only a small fraction of their people born overseas, Australia's foreign-born population is a substantial portion of both the population and the electorate. In the 1961 Australian census, 17 percent of the population was born overseas, and by 2001 , this had risen to 23 percent. ${ }^{12}$ Twenty-three percent of the voters in the 10 election surveys were born overseas (Table 1).

However, it should be noted that both the composition of the foreignborn population in Australia has changed somewhat since the 1960s. In 1961, 54 percent of the overseas-born were from non-English-speaking countries, and by 2001 , this had risen to 63 percent. If the difference between native-born and foreign-born Australians is driven by Labor's policies on multiculturalism (McAllister and Makkai, 1991), then those most affected will be likely to be voters whose first language is not English. The changing composition of the foreign-born population may explain at least part of the change in the foreign-born coefficient from 1966 to 2001.

\subsection{Who Swings?}

Before including regional and national characteristics in the model, I briefly digress to consider swing voters - those who report that they supported a different party in the previous election than they did in the current election. About one in 10 of voters said that they were swingers, meaning that they switched from one party to another between two successive elections (for a historical analysis of swing voting in Australia, see Goot, 1994, pp. 175-179).

In broad terms, two models might explain why voters change their party support from election to election. One model is that voters "swing" because they steadily acquire more information about the policies of the major parties over successive elections. This model would predict that volatility in

\footnotetext{
${ }^{12}$ Author's calculations, based on data from Department of Immigration and Multicultural Affairs, 2001, Immigration: Federation to Century's End, 1901-2000 (DIMA, Canberra) 18-19; and Australian Bureau of Statistics, 2004, "Population: country of birth" in Year Book Australia 2004 (ABS, Canberra).
} 
voting patterns would decline with age. An alternative model is that voters might swing because the parties themselves changed their policies. Unless this change was subsequently reversed, the coefficient for the favored or disfavored group should be significantly different from zero. Of course, the two models are not mutually exclusive.

How well do voters recall the way they cast their ballots in the election before last? One way of answering this question is to again compare the reported voting patterns with the actual vote share recorded by the Australian Electoral Commission. ${ }^{13}$ Although emigration and the passing of some older voters will mean that the composition of the current electorate is not fully reflective of the electorate at the previous poll, this method should still make it possible to discern any significant biases.

Columns (5) and (6) of Table 2 shows the results from this exercise. The mean absolute error is 3.6 percent, somewhat larger than when voters are asked how they voted in the last election ( 2.5 percent). The mean pro-winner bias is 2.5 percent, the mean pro-incumbent bias is 1.9 percent, and the mean pro-Labor bias is 2.6 percent - all larger in these "election before last" surveys than in the "last election" surveys. The bias is smallest when the survey is conducted after an election in which the incumbent has been ousted.

It is now possible to turn to analyzing the factors that are associated with vote-switching. Table 7 shows the results of a regression in which the dependent variable is not whether the respondent voted Labor, but whether she switched her allegiance. The dependent variable is 1 if the respondent voted for a different major party in the previous election and the current election, and 0 if she voted for the same party in both elections (this question was not asked in the survey following the 1966 election). As with the coding of the partisanship variable, I exclude those who did not respond, or said that they voted for a minor party in the previous election.

Column (1) of Table 7 suggests that younger voters, foreign-born voters, and men are all more likely to change their support from one party to the other. Yet this is only partially consistent with a policy-learning explanation. Foreign-born voters are more likely to switch parties than native-born voters, and equally likely to switch from the Coalition to Labor as from Labor to the Coalition, suggesting that those born overseas may be less committed to either of the major parties, and therefore more likely to switch between them. The data do not ask respondents how long they have been in Australia, but it would be an interesting question for further research to see whether foreign-born voters remain more likely to swing throughout their lives (suggesting that their degree of innate ideological attachment may be lower), or whether they become less likely over time to change their vote

\footnotetext{
${ }^{13}$ Of course, one cannot use the change in recorded primary vote share as a measure of the number of swing voters, since voters swinging in opposite directions will often cancel out one another.
} 
TABLe 7 Who Swings?

(Dependent variable: 1 if changed parties, 0 if same party)

\begin{tabular}{|c|c|c|c|}
\hline & $\begin{array}{c}\text { (1) } \\
\text { Swing voter } \\
\text { (either direction) }\end{array}$ & $\begin{array}{c}\text { (2) } \\
\text { Swung Coalition } \\
\text { to Labor }\end{array}$ & $\begin{array}{l}\text { (3) } \\
\text { Swung Labor } \\
\text { to Coalition }\end{array}$ \\
\hline Aged 30-39 & $\begin{array}{c}-0.010 \\
{[0.009]}\end{array}$ & $\begin{array}{c}-0.004 \\
{[0.006]}\end{array}$ & $\begin{array}{c}-0.005 \\
{[0.006]}\end{array}$ \\
\hline Aged 40-49 & $\begin{array}{c}-0.014 \\
{[0.009]}\end{array}$ & $\begin{array}{c}-0.010^{*} \\
{[0.006]}\end{array}$ & $\begin{array}{c}-0.003 \\
{[0.006]}\end{array}$ \\
\hline Aged 50-59 & $\begin{array}{c}-0.030^{* * *} \\
{[0.008]}\end{array}$ & $\begin{array}{c}-0.019^{* * *} \\
{[0.005]}\end{array}$ & $\begin{array}{c}-0.007 \\
{[0.006]}\end{array}$ \\
\hline Aged 60 or over & $\begin{array}{c}-0.039^{* * *} \\
{[0.008]}\end{array}$ & $\begin{array}{c}-0.025^{* * *} \\
{[0.005]}\end{array}$ & $\begin{array}{r}-0.011^{*} \\
{[0.006]}\end{array}$ \\
\hline Income quintile 2 & $\begin{array}{c}0.014 \\
{[0.010]}\end{array}$ & $\begin{array}{c}0.009 \\
{[0.007]}\end{array}$ & $\begin{array}{c}0.003 \\
{[0.006]}\end{array}$ \\
\hline Income quintile 3 & $\begin{array}{c}0.015 \\
{[0.010]}\end{array}$ & $\begin{array}{c}0.018^{* *} \\
{[0.008]}\end{array}$ & $\begin{array}{c}-0.004 \\
{[0.006]}\end{array}$ \\
\hline Income quintile 4 & $\begin{array}{c}0.006 \\
{[0.010]}\end{array}$ & $\begin{array}{c}0.005 \\
{[0.007]}\end{array}$ & $\begin{array}{l}0 \\
{[0.006]}\end{array}$ \\
\hline Income quintile 5 & $\begin{array}{c}0.011 \\
{[0.010]}\end{array}$ & $\begin{array}{c}0.006 \\
{[0.007]}\end{array}$ & $\begin{array}{c}0.002 \\
{[0.007]}\end{array}$ \\
\hline High school graduation only & $\begin{array}{c}-0.012 \\
{[0.009]}\end{array}$ & $\begin{array}{c}-0.014^{* * *} \\
{[0.005]}\end{array}$ & $\begin{array}{c}0.005 \\
{[0.007]}\end{array}$ \\
\hline Diploma/trade qualification & $\begin{array}{c}-0.004 \\
{[0.007]}\end{array}$ & $\begin{array}{c}0.004 \\
{[0.005]}\end{array}$ & $\begin{array}{c}-0.007 \\
{[0.005]}\end{array}$ \\
\hline University degree & $\begin{array}{c}-0.008 \\
{[0.009]}\end{array}$ & $\begin{array}{c}-0.011^{* *} \\
{[0.006]}\end{array}$ & $\begin{array}{c}0.003 \\
{[0.006]}\end{array}$ \\
\hline Born overseas & $\begin{array}{l}0.041^{* * *} \\
{[0.008]}\end{array}$ & $\begin{array}{l}0.020^{* * *} \\
{[0.005]}\end{array}$ & $\begin{array}{l}0.019^{* * *} \\
{[0.005]}\end{array}$ \\
\hline Female & $\begin{array}{c}-0.010^{*} \\
{[0.006]}\end{array}$ & $\begin{array}{c}-0.003 \\
{[0.004]}\end{array}$ & $\begin{array}{c}-0.006 \\
{[0.004]}\end{array}$ \\
\hline Married & $\begin{array}{c}0.004 \\
{[0.008]}\end{array}$ & $\begin{array}{c}0.000 \\
{[0.005]}\end{array}$ & $\begin{array}{c}0.003 \\
{[0.005]}\end{array}$ \\
\hline Divorced & $\begin{array}{c}0.007 \\
{[0.013]}\end{array}$ & $\begin{array}{c}0.015 \\
{[0.010]}\end{array}$ & $\begin{array}{c}-0.009 \\
{[0.008]}\end{array}$ \\
\hline Election FE? & Yes & Yes & Yes \\
\hline Observations & 11,043 & 11,043 & 11,043 \\
\hline Pseudo- $R^{2}$ & 0.03 & 0.06 & 0.05 \\
\hline Observed probability & 0.10 & 0.05 & 0.05 \\
\hline
\end{tabular}

Notes: Coefficients are marginal effects from a probit model. ${ }^{*},{ }^{* *}$, and ${ }^{* * *}$ denote statistical significance at the $10 \%, 5 \%$, and $1 \%$ level, respectively. Robust standard errors in square brackets. Excluded categories are as follows: age - those aged 18-29; income - first quintile; education - high school dropouts.

(suggesting that, over successive elections, they learn more about which major party best serves their interests). ${ }^{14}$

\footnotetext{
${ }^{14}$ Alternatively, it might be the case that these groups are less able to correctly recall how they voted in the previous election.
} 
The other significant result from column (1) of Table 7 is that older voters tend to be less likely to switch between parties. However, age seems to reduce the number of people who switch from the Coalition to Labor more than it reduces the number of people who switch from Labor to the Coalition. This suggests that two phenomena are occurring: voters seem to learn more about the major parties as they grow older; but older voters appear to be more loyal ("rusted on") to the Coalition than they are to Labor, indicating that the Coalition's policies have become relatively more favorable to the elderly.

Further evidence of the shifting policy explanation can be found among three other groups. High school graduates and those with a university degree were particularly loyal to the Coalition, while middle-income voters appeared especially inclined to switch to Labor.

\section{NEIGHBORHOOD-LEVEL FACTORS}

Next, I consider whether neighborhood-level factors influence voting patterns. Characteristics of a neighborhood may have a direct effect upon voters' behavior in a number of ways. In more diverse neighborhoods, voters may experience a greater positive or negative externality from policies that affect other groups. For example, a voter in an ethnically diverse neighborhood may experience a positive externality from more generous welfare programs for those born overseas; while for a voter in an unequal neighborhood may feel some positive externality if more generous housing subsidies are provided. Even in the absence of policy spillovers, neighborhood composition may affect voting patterns if individuals feel some sense of altruism towards those who live in their local area. And a third possibility is that there may be some local interaction effect, by which a person who is a member of Group A comes to favor the interests of that group more strongly as the share of the neighborhood that are members of Group A expands.

However, when analyzing neighborhood effects, it is important to recognize that where voters choose to live is often endogenous to their policy preferences. Thus a rich person who favors pro-poor policies may choose to live in a low-income neighborhood. Naive ordinary least squares (OLS) or probit models that do not take this into account may derive biased estimates of the true neighborhood effects. A possible solution to this problem was proposed by Dustmann and Preston (2001), who posit that families choose where to live at a very local level, but are constrained at a regional level - by factors such as a desire to be near their place of work, or to be within a reasonable proximity of family and friends. Using data from the UK, Dustmann and Preston instrument for racial composition in a ward (average size: 5,000 people) with racial composition in the surrounding district (average size: 125,000 people) or county (average size: 1 million people).

A similar approach can be applied in the present case. Using data from the 1996 census, I am able to form measures of the composition of postal code 
areas (which I will term "neighborhoods"). Because the Australian Bureau of Statistics provides a full tabulation of the census at this level, the measures are unaffected by sampling problems (see the Data Appendix for details). The mean population in a neighborhood (postcode area) is about 17,000 people. I then calculate statistics at the regional level, where regions are areas of about 450,000 people. Regions are either part of a major city, an entire minor city, part of a large state, or an entire small state or territory. For example, Parramatta, Tasmania, North Queensland, and the Gold Coast are all distinct regions. Respondents in the sample are spread across 3,350 neighborhoods and 54 regions.

Before using the IV strategy, I first estimate a naive model, in which the neighborhood characteristics enter directly into the model. If $\delta$ is a vector of characteristics of neighborhood $j$ :

$$
\operatorname{Pr}(\text { VoteLabor })_{i j t}=\alpha+\beta Z_{i j t}+\delta_{j}+\gamma_{t}+\varepsilon_{i j t} .
$$

Columns (1) and (2) of Table 8 present the results from this specification. Since I only have data on neighborhood composition from the 1996 census, the sample is restricted to the 1993, 1996, 1998, and 2001 Australian Election Studies. Standard errors are clustered at the neighborhood level.

The results of this specification suggest that individuals in richer neighborhoods are more likely to vote for the Coalition, controlling for the individual's own income. A 10 percent rise in mean neighborhood income, according to the naive model, raises by 2 percent the probability that the respondent will vote for the Coalition. Conversely, a 10 percentage point rise in the foreign-born population (about one standard deviation) boosts the Labor vote by about 4 percent. Inequality in the naive model has no effect on vote share. Further, it makes virtually no difference whether the model is estimated using probit or OLS.

However, because an individual's neighborhood may be endogenous, I now estimate a two-stage model, in which $\delta_{k}$ is a vector of characteristics of region $k$.

$$
\begin{aligned}
& \text { Stage1: } \delta_{j}=\lambda+\rho Z_{i j k t}+\delta_{k}+\gamma_{t}+v_{i j k t} \\
& \text { Stage2: } \operatorname{Pr}(\text { VoteLabor })_{i j t}=\alpha+\beta Z_{i j t}+\hat{\delta}_{j}+\gamma_{t}+\varepsilon_{i j t} .
\end{aligned}
$$

Because Stata does not facilitate clustering of standard errors in a probit IV model, I instead estimate the equation using a linear IV model, clustering standard errors at the neighborhood level.

Column (3) of Table 8 shows the results for this specification. The causal effect of living in a rich neighborhood appears to be somewhat larger than in the naive model - with a 10 percent rise in mean neighborhood income boosting by 3 percent the probability that the respondent will vote for the Coalition. However, the causal effect of living in a neighborhood with a 
Table 8 Neighborhood-Level Factors (1993-2001 ONLY)

(Dependent variable: 1 if voted Labor, 0 if voted Coalition)

\begin{tabular}{lccc}
\hline & $(1)$ & $(2)$ & $(3)$ \\
& Probit & OLS & IV \\
\hline Log mean neighborhood income & $-0.186^{* * *}$ & $-0.178^{* * *}$ & $-0.313^{* * *}$ \\
& {$[0.049]$} & {$[0.046]$} & {$[0.093]$} \\
Inequality in neighborhood (Gini) & -0.268 & -0.25 & $3.160^{* * *}$ \\
& {$[0.359]$} & {$[0.342]$} & {$[0.986]$} \\
Fraction born overseas & $0.373^{* * *}$ & $0.355^{* * *}$ & $0.254^{* * *}$ \\
& {$[0.069]$} & {$[0.065]$} & {$[0.096]$} \\
Controls for age, income, education, & Yes & Yes & Yes \\
sex, born overseas, marital status? & & & \\
Election FE? & Yes & Yes & Yes \\
Observations & 5,894 & 5,894 & 5,894 \\
Pseudo- $R^{2}$ or $R^{2}$ & 0.04 & 0.06 & 0.04 \\
Observed probability & 0.47 & & \\
\hline
\end{tabular}

Notes: Column (1) shows marginal effects from a probit model; column (2) shows OLS coefficients; and column (3) shows coefficients from a linear IV model, instrumenting for neighborhood-level characteristics with regional characteristics. ${ }^{*},{ }^{* *}$, and ${ }^{* * *}$ denote statistical significance at the $10 \%, 5 \%$, and $1 \%$ level, respectively. Robust standard errors, clustered at the neighborhood level, in square brackets.

higher fraction born overseas falls in the IV specification, with a 10 percent rise in foreign-born share leading to a 2.5 percent increase in the probability that a respondent will vote Labor. Since the standard deviation of foreign-born across neighborhoods is 0.12 , a one-standard-deviation increase in the foreignborn share is associated with a 3 percentage point rise in the Labor vote.

Interestingly, while inequality had no effect in the naive model, there seems to be a strong causal relationship between higher neighborhood inequality and an individual's propensity to vote Labor. The coefficient on the effect is -3.1 , suggesting that a two-point rise in the Gini (the standard deviation between neighborhoods) is associated with a 6 percent rise in an individual's propensity to vote Labor. Comparing a one-standard-deviation increase in inequality with a one-standard-deviation increase in foreign-born, it appears that the "inequality effect" is larger than the "foreign-born effect."

How do the neighborhood effects operate? To see whether there is heterogeneity in the neighborhood effects, Table 9 shows the results from interacting the neighborhood-level characteristics with individual characteristics. As with equations (5) and (6), the interacted variables in Table 9 are neighborhood-level interactions, but instrumented by their regional-level counterparts. In analyzing the relationships, I assume that Labor governments tend to be more generous to the poor, and to those who were born overseas - which is consistent with the foregoing findings that poorer and foreign-born voters are more likely to support Labor. 
Table 9 Neighborhood-Level Factors Interacted with Individual Factors (1993-2001 ONLY)

(Dependent variable: 1 if voted Labor, 0 if voted Coalition)

\begin{tabular}{|c|c|c|c|}
\hline & $\begin{array}{l}(1) \\
\text { IV }\end{array}$ & $\begin{array}{l}\text { (2) } \\
\text { IV }\end{array}$ & $\begin{array}{l}\text { (3) } \\
\text { IV }\end{array}$ \\
\hline Log mean neighborhood income & & $\begin{array}{l}-0.300^{* * *} \\
{[0.095]}\end{array}$ & $\begin{array}{l}-0.309^{* * *} \\
{[0.094]}\end{array}$ \\
\hline Inequality in neighborhood & $\begin{array}{l}3.237^{* * *} \\
{[0.970]}\end{array}$ & $\begin{array}{l}3.114^{* * *} \\
{[0.988]}\end{array}$ & \\
\hline Fraction born overseas & $\begin{array}{l}0.256^{* * *} \\
{[0.097]}\end{array}$ & & $\begin{array}{l}0.251^{* * *} \\
{[0.096]}\end{array}$ \\
\hline Mean income $*$ Income quintile 1 & $\begin{array}{l}-0.559^{* * *} \\
{[0.148]}\end{array}$ & & \\
\hline Mean income $*$ Income quintile 2 & $\begin{array}{l}-0.005 \\
{[0.131]}\end{array}$ & & \\
\hline Mean income $*$ Income quintile 3 & $\begin{array}{l}-0.375^{* *} \\
{[0.158]}\end{array}$ & & \\
\hline Mean income $*$ Income quintile 4 & $\begin{array}{c}-0.281^{* *} \\
{[0.141]}\end{array}$ & & \\
\hline Mean income $*$ Income quintile 5 & $\begin{array}{l}-0.360^{* * *} \\
{[0.138]}\end{array}$ & & \\
\hline Fraction overseas born $*$ Native & & $\begin{array}{c}0.181^{*} \\
{[0.108]}\end{array}$ & \\
\hline Fraction overseas born $*$ Born OS & & $\begin{array}{l}0.460^{* * *} \\
{[0.155]}\end{array}$ & \\
\hline Inequality $*$ Income quintile 1 & & & $\begin{array}{c}1.663 \\
{[1.587]}\end{array}$ \\
\hline Inequality $*$ Income quintile 2 & & & $\begin{array}{l}4.366^{* * *} \\
{[1.535]}\end{array}$ \\
\hline Inequality $*$ Income quintile 3 & & & $\begin{array}{r}2.972^{*} \\
{[1.726]}\end{array}$ \\
\hline Inequality $*$ Income quintile 4 & & & $\begin{array}{l}4.023^{* * *} \\
{[1.542]}\end{array}$ \\
\hline Inequality $*$ Income quintile 5 & & & $\begin{array}{l}2.898^{* *} \\
{[1.471]}\end{array}$ \\
\hline $\begin{array}{l}\text { Controls for age, income, education, } \\
\text { sex, born overseas, marital status? }\end{array}$ & Yes & Yes & Yes \\
\hline Election FE? & Yes & Yes & Yes \\
\hline Observations & 5,894 & 5,894 & 5,894 \\
\hline$R^{2}$ & 0.04 & 0.04 & 0.04 \\
\hline
\end{tabular}

Notes: All three specifications instrument for neighborhood-level characteristics (and neighborhood-individual interactions) with regional characteristics (and regional-individual interactions). ${ }^{*},{ }^{* *}$, and ${ }^{* * *}$ denote statistical significance at the $10 \%, 5 \%$, and $1 \%$ level, respectively. Robust standard errors, clustered at the neighborhood level, in square brackets.

To begin with, column (1) of Table 9 interacts mean neighborhood income with an individual's income. The pro-Coalition effect of living in a richer neighborhood appears to be strongest for the bottom 20 percent of the distribution (most consistent with a spillover or altruism explanation), with 
no significant effect on the second quintile. The impact on the top 60 percent of the distribution is similar (suggesting a local interaction effect).

Column (2) interacts the fraction born overseas in a neighborhood with whether the individual was born overseas. The effect of neighborhood ethnic composition is more than twice as large for the foreign-born population, suggesting that the ethnic composition effect may operate through immigrant organizations and networks, which would lead to both positive externalities and local interaction effects.

The third column of Table 9 interacts neighborhood inequality with individual income. Greater neighborhood-level inequality appears to make the top four-fifths of the distribution more likely to vote Labor, but not the very poor. The inequality interaction results are consistent with either a spillover explanation (in which more generous programs for the poor have a positive externality for their more affluent neighbors), or with a local interaction explanation (in which rich voters in a more unequal neighborhood are more likely to come into contact with the poor).

\section{MACROECONOMIC VARIABLES}

Finally, I analyze the effect of macroeconomic factors on the decision to vote Labor. A number of Australian papers have shown a systemic relationship between macroeconomic outcomes and the incumbent vote share (Jackman and Marks, 1994; Jackman, 1995; Cameron and Crosby, 2000), and out-ofsample, the state of the macroeconomy has been shown to be a moderately accurate predictor of whether an incumbent government will be elected (Wolfers and Leigh, 2002). When unemployment, inflation, GDP, and the real wage are all included in the model, the two significant predictors of reelection are unemployment and inflation, which are both negatively correlated with the incumbent party's vote share (Cameron and Crosby, 2000; Wolfers and Leigh, 2002). Table 10 replicates these results for the 39 federal elections from 1903-2001, using the full specification of Cameron and Crosby [column (1)], and a more parsimonious specification, with only unemployment and inflation [column (2)].

But aside from rewarding good economic management and punishing bad performance, do voters' preferences for Labor or Coalition governments vary according to the economic cycle? To test this, I re-estimate these two macroeconomic models, now using the Labor Party's share of the major party vote as the dependent variable, in place of the incumbent party vote share. To take into account the possibility that the Labor vote varies systematically with whether the party is in power, I also include a dummy variable denoting whether the Labor Party was the incumbent.

Table 10 shows the results from this regression, with the full Cameron and Crosby specification [column (3)], and with just unemployment and inflation [column (4)]. In both cases, the coefficients on the macroeconomic variables 
TABLe 10 Macroeconomic FaCtors (1993-2001)

\begin{tabular}{|c|c|c|c|c|}
\hline \multirow{4}{*}{$\begin{array}{l}\text { Dependent variable: } \\
\text { Unemployment rate }\end{array}$} & (1) & (2) & (3) & (4) \\
\hline & \multicolumn{2}{|c|}{ Incumbent vote share } & \multicolumn{2}{|c|}{ Labor Party vote share } \\
\hline & $-0.306^{*}$ & $-0.424^{*}$ & 0.053 & -0.289 \\
\hline & {$[0.160]$} & {$[0.251]$} & {$[0.220]$} & {$[0.272]$} \\
\hline \multirow[t]{2}{*}{ Inflation } & $-0.374^{* * *}$ & -0.199 & -0.094 & -0.117 \\
\hline & {$[0.115]$} & {$[0.175]$} & {$[0.179]$} & [0.194] \\
\hline \multirow[t]{2}{*}{ Real GDP growth } & -0.207 & & -0.155 & \\
\hline & {$[0.161]$} & & {$[0.221]$} & \\
\hline \multirow[t]{2}{*}{ Real wage growth } & $-0.275^{*}$ & & 0.027 & \\
\hline & {$[0.158]$} & & {$[0.237]$} & \\
\hline \multirow[t]{2}{*}{ Honeymoon } & $4.313^{* *}$ & & 1.127 & \\
\hline & [1.749] & & {$[2.135]$} & \\
\hline \multirow[t]{2}{*}{ Labor incumbent } & & & $3.572^{* * *}$ & $4.001^{* *}$ \\
\hline & & & {$[1.224]$} & [1.921] \\
\hline Observations & 39 & 39 & 39 & 39 \\
\hline$R^{2}$ & 0.77 & 0.1 & 0.66 & 0.15 \\
\hline
\end{tabular}

Notes: Following Cameron and Crosby (2000), unemployment rate is in the election quarter, while inflation, GDP growth, and real wage growth are in the year prior to the election. Specifications in columns (1) and (3) follow Cameron and Crosby by including indicator variables for the elections of 1906, 1931, and 1975, plus separate dummies for the two world wars. ${ }^{*},{ }^{* *}$, and ${ }^{* * *}$ denote statistical significance at the $10 \%, 5 \%$, and $1 \%$ level, respectively. Robust standard errors in square brackets.

are statistically indistinguishable from zero. This is consistent with Cameron and Crosby's finding that the interaction between the party in power and the state of the macroeconomy is statistically insignificant.

\section{CONCLUSION}

Better understanding what makes individuals support a left-wing or rightwing party can provide new insights into how each party's policies affect different groups in the population. The foregoing results suggest a number of systematic patterns. At an individual level, the poor, foreign-born, younger voters, voters born since 1950 , men, and unmarried voters are more likely to support the Labor Party. High school graduates and those with a trade qualification are also more likely to be Labor voters than high school dropouts and university graduates, but much of this appears to be a permanent income effect. Some degree of party polarization also seems to have occurred. Over the past 35 years, the partisan gap has widened on a number of dimensions: between young and old; between rich and poor; and between native-born and foreign-born. However, the gender gap, which once saw women favor the Coalition by 14 percent, appears to have closed.

Neighborhood effects also seem to be important. Controlling for a respondent's own characteristics, and instrumenting for neighborhood 
characteristics, voters who live in richer neighborhoods are more likely to vote for the Coalition, while those in more ethnically diverse or unequal neighborhoods are more likely to support Labor. By contrast, no systematic pattern seems to emerge from the macroeconomic data. Australian voters reward good economic management, but appear to regard the parties as equally capable of governing in good times and bad.

Yet despite these distinct and significant patterns, we have still not accounted for a large portion of the variance in voting behavior across the population. The $R^{2}$ statistics indicate that the chosen set of individual characteristics (and the election fixed effects) explain just 3 percent of voting behavior. Adding either birth cohort or neighborhood characteristics explains an additional 1 percent. A full 96 percent of the variation in voting behavior across individuals therefore remains unexplained. Returning to the nomenclature of the voting model set out in section 1, we have modeled $X 1$ (the observable groups to which an individual belongs), $X 3$ (characteristics of the individual's neighborhood), and $X 4$ (national economic variables). What remains is $X 2$ (unobservable group characteristics) and $X 5$ (the voter's innate ideological tendency). Given that observable group characteristics account for only a small portion of variance in voting behavior, I speculate that unobservable group characteristics probably only account for a relatively small fraction of the remaining variance. Notwithstanding many strong and systematic patterns in the data, a large portion of voter behavior appears to be driven by innate individual characteristics, such as childhood socialization.

\section{DATA APPENDIX}

The surveys used in this paper are those which included questions on which party the respondent voted for in the previous election, plus a set of demographic variables. Those selected to be most important were age, sex, education, marital status, family income, and whether the respondent was born overseas. Of these, the last two variables turned out to be the most problematic. The 1987 and 1990 Australian Election Studies were excluded on the basis that they did not ask respondents any questions about income, while the National Social Science Survey: 1990 Election Panel Survey was excluded on the basis that it did not ask respondents whether they were born overseas (frustratingly, no 1990 election survey asked respondents about both income and whether they were born overseas). All of the election surveys used in this paper were of the mail-out type.

Generally speaking, comparisons of the demographics in the Australian Election Studies and the National Social Science Surveys suggest that the two surveys were similarly representative of the population. However, as Goot (2000, p. 48) has shown, tertiary-educated respondents were overrepresented in the AES - perhaps because it was conducted by mail. Neither 
set of surveys appeared to suffer from a noticeably greater degree of prowinner bias than the other (see Table 2).

Due to data restrictions imposed by the Australian Social Science Data Archives, it is not possible to make the dataset used in this paper publicly available. However, I would be happy to supply other researchers with the Stata program used to create the dataset. Those interested in using multiple Australian election surveys over a more recent period may also wish to contact Sinclair Davidson, Tim Fry, and Lisa Farrell, who are presently creating a dataset based on all variables from the 1987-2004 Australian Election Studies ("Economic Reform and Australian Electoral Decision Making," ARC Grant DP0449846).

Coding of variables was straightforward in most cases. Some notes on particular variables appear below.

\section{Education}

Educational attainment was coded into four categories: high school dropouts, high school graduates, some college or a trade qualification, and college degree (more detailed information on education existed in some, but not all, surveys).

\section{Income}

There was some variation in the number of income categories across surveys. There were eight income categories in 1966, 1969, and 1977, 11 categories in 1983, 1,087 in 1984, 108 in 1987, 14 in 1993 and 1996, and 16 in 1998 and 2001. Except for 1984 and 1987, income was presented as a range, and individuals in each range were coded as having family income at the midpoint of the range, or 1.15 times the upper limit in the case of those in the top category. Lastly, it should be noted that, as a consequence of this categorization and the underlying distribution of incomes, no respondents in 1966 fell into the third income quintile.

Age

The voting age in Australia was 21 until 1973, when it was lowered to 18. In most cases, the survey was restricted to those who were eligible to vote, but in the few cases where respondents report an age that would have made them ineligible to cast a ballot, they were dropped from the sample.

\section{Divorced}

In the 1983 survey, the categories "widowed" and "divorced" are combined into a single category widowed/divorced. To avoid discarding the 1983 survey altogether, I explored the age profile of widowed and divorced individuals in the earlier survey (1977, since there was no survey for 1980) and 
the subsequent survey (1984). In these two surveys, almost no younger women are widowed, and almost no older women are divorced. Of the 208 respondents who ticked "widowed/divorced" in 1983, I therefore assume that all widowed/divorced aged under 55 are divorced (99 respondents), and all widowed/divorced aged over 55 are widowed (109 respondents).

\section{Trade Union Membership}

With the exception of the 1983 election survey, all other surveys used in this analysis included a question on trade union membership. This question had virtually identical wording in all surveys except 1993. In 1993, the question allowed the respondent to select either "trade union" or "staff association" (this was also the question in the 1990 AES, but that survey is not used here).

Although Leithner (1997) distinguishes these two groupings, it seems more likely that those who marked "staff association" would have marked "trade union" if it were the only option. To see this, note that if we combine "trade union" and "staff association" in 1993, the overall unionization figures appear to be $41.8 \%$ (1987), $29.5 \%$ (1993), 29.8\% (1996). Alternatively, if we omit members of staff associations from the 1993 figure, union membership for the three years appears to be $41.8 \%$ (1987), $23.4 \%$ (1993), $29.8 \%$ (1996). This would be inconsistent with ABS surveys, which show a steady decline in union membership over this period, not a rise between 1993 and 1996. See Australian Bureau of Statistics, 1997, Trade Union Members, Australia. Cat. No. 6325.0 (ABS, Canberra). (Note that while trends in trade union membership in the election surveys should be approximately comparable with ABS surveys, the levels are lower in the election surveys, since the ABS measures trade union membership as a fraction of employees, not the entire population.)

\section{Weights}

Only the 1993 survey is weighted. For all other surveys, each individual is assigned a weight of 1 . The weights are then recoded so as to balance the sample across elections, by ensuring that the sum of the weights for each election is 2000 .

\section{Postal Code Variables}

For the 1996, 1998, and 2001 surveys, the postcode variable is only available on a confidential version of the survey instrument. I am grateful to the Australian Social Science Data Archive for temporarily sharing this confidentialized dataset with me.

\section{Regions}

Regions are defined as Australia Post BSP regions. 


\section{Postal Code-Level Variables}

Postcode-level variables are constructed from the 1996 census, for which the Australian Bureau of Statistics has published a full tabulation of income and birthplace by postcode (Australian Bureau of Statistics, 1997, CDATA 1996 CD-ROM, ABS, Canberra). Using these data, I create precise measures of log mean weekly individual income, fraction born overseas, and inequality among individuals (as measured by the Gini coefficient) for each postcode area and region, unaffected by sample size problems.

\section{Macroeconomic Variables}

I am grateful to Lisa Cameron and Mark Crosby for sharing their dataset, which was subsequently updated by Justin Wolfers and myself (for more details, see Wolfers and Leigh, 2002).

APPENDIX TABLE A. ELECTIONS IN SAMPLE

\begin{tabular}{ll}
\hline Election & Study \\
\hline
\end{tabular}

1966 D. Aitkin, M. Kahan, and D. Stokes, 1967, Australian National Political Attitudes (ICPR Study No. 7282) (InterUniversity Consortium for Political and Social Research, Ann Arbor, Michigan)

1969

D. Aitkin, M. Kahan, and D. Stokes, 1969, Australian National Political Attitudes (ICPR Study No. 7393) (InterUniversity Consortium for Political and Social Research, Ann Arbor, Michigan)

1977 D. Aitken, 1979, Macquarie University Australian Political Attitudes Survey (ASSDA No. 9) (Australian National University, Social Science Data Archives, Canberra)

1983

1984

T. Beed, E. M. Goot, and J. Reark, 1983, Reark PostElection Survey (SSDA Study No. D0158) (Australian National University, Social Science Data Archives, Canberra)

J. Kelley, R. Cushing, and B. Headey, 1984, Australian National Social Science Survey (ICPSR 9084) (Inter-University Consortium for Political and Social Research, Ann Arbor, Michigan)

1987

J. Kelley, C. Bean, and M. Evans, 1988, National Social Science Survey 1987-1988: Inequality (SSDA Study No. 627) (Australian National University, Social Science Data Archives, Canberra) 
APPENDIX TABLE A. Continued

\begin{tabular}{ll}
\hline Election & \multicolumn{2}{c}{ Study } \\
\hline 1993 & R. Jones, I. McAllister, D. Denemark, and D. Gow, 1993, \\
& Australian Election Study (SSDA Study No. 763) (Aus- \\
& tralian National University, Social Science Data Archives, \\
& Canberra) \\
& R. Jones, I. McAllister, and D. Gow, 1996, Australian \\
& Election Study (SSDA Study No. 943) (Australian National \\
& University, Social Science Data Archives, Canberra) \\
& C. Bean, D. Gow, and I. McAllister, 1998, Australian \\
& Election Study (SSDA Study No. 1001) (Australian Na- \\
& tional University, Social Science Data Archives, Canberra) \\
& C. Bean, D. Gow, and I. McAllister, 2001, Australian \\
& Election Study (SSDA Study No. 1048) (Australian Na- \\
& tional University, Social Science Data Archives, Canberra)
\end{tabular}

\section{ANDREW LEIGH}

Research School of Social Sciences, Australian National University

\section{REFERENCES}

Aitkin, D., 1982, Stability and Change in Australian Politics, 2nd edn. (ANU Press, Canberra).

Alesina, A. and H. Rosenthal, 1995, Partisan Politics, Divided Government, and the Economy (Cambridge University Press, Cambridge, UK).

Alt, J. and R. Lowry, 2000, A dynamic model of state budget outcomes under divided partisan government. Journal of Politics 62(4), 1035-1069.

Bartels, L., 2003, Partisan politics and the US income distribution. Mimeo, Princeton University.

Cameron, L. and M. Crosby, 2000, It's the economy stupid: macroeconomics and federal elections in Australia. Economic Record 76(235), 354-364.

Campbell, A., P. Converse, W. Miller, and D. Stokes, 1960, The American Voter (University of Chicago Press, Chicago). New York).

Charnock, D., 1997, Class and voting in the 1996 Australian federal election. Electoral Studies 16, 281-300.

Downs, A., 1957, An Economic Theory of Democracy (HarperCollins, New York).

Dustmann, C. and I. Preston, 2001, Attitudes to ethnic minorities, ethnic context and location decisions. Economic Journal 111(470), 353-373.

Edlund, L. and R. Pande, 2001, Why have women become left-wing? The political gender gap and the decline in marriage. Quarterly Journal of Economics 117(3), 917-961. 
- L. Laider, and R. Pande, 2005, Unmarried parenthood and redistributive politics. Journal of the European Economic Association 3(1), 95-119.

Franklin, C., 1984, Issue preferences, socialization, and the evolution of party identification. American Journal of Political Science 28, 459-478.

Goot, M., 1994, Class voting, issue voting and electoral volatility, in: J. Brett, J. Gillespie, and M. Goot, eds., Developments in Australian Politics (Macmillan, Melbourne) 153-181.

__ 2000, More "relaxed and comfortable": public opinion on immigration under Howard. People and Place 8(3), 46-60.

- 2004, Party convergence reconsidered. Australian Journal of Political Science 39(1), 49-73.

Gow, D., 1990, Economic voting and postmaterialist values, in: C. Bean, I. McAllister, and J. Warhurst, eds., The Greening of Australian Politics: The 1990 Federal Election (Longman Cheshire, Melbourne).

Grattan, M., 2004, It's on for young and old. The Age, February 8.

Green, D. and B. Palmquist, 1990, Of artifacts and partisan instability. American Journal of Political Science 34, 872-901.

Haider, S. J. and G. Solon, 2004, Life-cycle variation in the association between current and lifetime earnings. Mimeo, Michigan State University.

Jackman, S., 1995, Some more of all that: a reply to Charnock. Australian Journal of Political Science 30, 347-355.

__ 2003, Political parties and electoral behavior, in: I. McAllister, S. Dowrick, and R. Hassan, eds., Cambridge Handbook of the Social Sciences in Australia (Cambridge University Press, Melbourne).

— and G. Marks, 1994, Forecasting Australia elections: 1993, and all that. Australian Journal of Political Science 29(2), 277-291.

Leigh, A., 2004, Deriving long-run inequality series from tax data. Australian National University Centre for Economic Policy Research Discussion Paper No. 476.

$\ldots$ - 2005, What's the difference between a donkey and an elephant? Measuring the impact of partisanship on social and economic outcomes. Mimeo, Australian National University.

Leithner, C., 1997, A gender gap in Australia? Commonwealth elections 1910-96. Australian Journal of Political Science 32(1), 29-47.

Lewis-Beck, M., 1986, Comparative economic voting: Britain, France, Germany, Italy. American Journal of Political Science 30, 315-346.

Lijphart, A., 1971, Class and Religious Voting in the European Democracies (University of Strathclyde Press, Glasgow).

McAllister, I., 1992, Political Behavior: Citizens, Parties and Elites in Australia (Longman Cheshire, Melbourne).

— and T. Makkai, 1991, The formation and development of party loyalties: patterns among Australian immigrants. Australia and New Zealand Journal of Sociology 27(2), 195-217.

Marks, G., 1993, Partisanship and the vote in Australia: changes over time 19671990. Political Behavior 15(2), 137-166.

Markus, G., 1988, The impact of personal and national economic conditions on the presidential vote: a pooled cross sectional analysis. American Journal of Political Science 32, 137-154.

Mayer, H., 1980, Big party chauvinism and minor party romanticism, in: H. Mayer and H. Nelson, eds., Australian Politics: A Fifth Reader (Longman Cheshire, Melbourne) 345-360.

Renfrow, P., 1994, The gender gap in the 1993 election. Australian Journal of Political Science 29 (Special Issue), 118-133. 
Roemer, J., 2001, Political Competition: Theory and Applications (Harvard University Press, Cambridge, MA).

Stonecash, J. and M. Mariani, 2000, Republican gains in the House in the 1994 elections: class polarization in American politics. Political Science Quarterly $115(1), 93-114$.

Western, M. and B. Tranter, 2001, Postmaterialist and economic voting in Australia, 1990-98. Australian Journal of Political Science 36(3), 439-458.

Weston, R. and B. Smyth, 2000, Financial living standards after divorce. Family Matters (Australian Institute of Family Studies) 55, 11-15.

Wolfers, J. and A. Leigh, 2002, Three tools for forecasting federal elections: lessons from 2001. Australian Journal of Political Science 37(2), 223-240. 